\title{
Severe undernutrition in growing and adult animals
}

\author{
11.* The first effects of rehabilitation on the metabolic \\ rate and body temperature
}

\author{
BY L. E. MOUNT \\ A.R.C. Institute of Animal Physiology, Babraham, Cambridge \\ AND D. LISTER AND R. A. McCANCE \\ Medical Research Council Department of Experimental Medicine, \\ University of Cambridge
}

(Received 12 March 1963-Rerised 25 April 1963)

In a previous paper (McCance \& Mount, r960) it was shown that piglets which had been undernourished for a year, and which weighed in consequence only some $6 \mathrm{~kg}$, had subnormal skin and deep-body temperatures. Their oxygen consumption rates were of the order of $12 \mathrm{ml} / \mathrm{kg} \min$ at $\mathrm{II}^{\circ}$ and $10 \mathrm{ml} / \mathrm{kg}$ min at $30^{\circ}$. The $\mathrm{O}_{2}$ consumption rates of normal animals of the same size were of the order of $17 \mathrm{ml} / \mathrm{kg} \mathrm{min}$ at $\mathrm{II}^{\circ}$ and I $1.5 \mathrm{ml} / \mathrm{kg} \min$ at $30^{\circ}$.

The first effects of rehabilitation on a series of undernourished pigs and cockerels are reported in this paper.

\section{EXPERIMENTAL}

Twenty-three pigs were used, of which six were normal pigs weighing about the same as the undernourished or rehabilitating ones. The procedures for metabolic measurements and for the housing and feeding were similar to those described by McCance ( 1960 ) and McCance \& Mount ( 1960 ) and the duration of undernutrition was I year. Thirteen undernourished cockerels were used, reared in three groups over a period of 2 years, and nine normal birds; they were fed and brought to the laboratory on the days of the test in the manner adopted for the pigs. In the earlier experiments the four or five birds of each group were placed together in the metabolism chamber at one time, and the $\mathrm{O}_{2}$ uptake of the group was determined, but later each bird was examined separately. All other measurements were made on the individual birds which were all undernourished for 6 months.

When the animals had been studied in the undernourished state, they were given extra food and rehabilitated as quickly as possible. Just at first they were fed individually, as they had been all the time they were undernourished, and they were offered small amounts of food repeatedly but never much at a time. Unless their food intake was being measured, they were allowed to eat to capacity at all times of the day or night after the first one or two days and measurements of body temperature and $\mathrm{O}_{2}$ consumption were repeated at intervals. 
The $\mathrm{O}_{2}$ consumption of the pigs was measured at $1 \mathrm{I}^{\circ}$ and at $30^{\circ}$ ambient temperature. The cockerels were studied at $30^{\circ}$, which had been shown by preparatory work to be within their thermoneutral zone. The aim was to study the pigs until they had doubled their initial weight. Some of them, however, had to be killed for other investigations before this time, and some became too large for the respirometer. The investigations, moreover, interfered with their rehabilitation to some extent, so that there had to be some compromise between the advantages of rapid growth and numerous determinations of metabolic rates. Each pig, therefore, was investigated $(a)$ when it was undernourished, $(b)$ on one or two of the intermediate days of rehabilitation which were the 2 nd, $3^{\text {rd, }} 4^{\text {th }}$ or $5^{\text {th }}$, and $(c)$ on the final day of the experiment, which varied from the 8 th to 2 th. The values for all the undernourished pigs were averaged. The majority of the animals were studied on the $4^{\text {th }}$ and Ioth days of rehabilitation. Values for the other animals on these days were obtained graphically from the lines that joined the results for the days on which they had been investigated, or from extrapolation to the roth day. Mean values were then calculated for the $4^{\text {th }}$ and roth days. The cockerels were studied more frequently during rehabilitation, and each of the three groups was investigated once during undernutrition, and subsequently on the 2nd, 6 th, 9 th and 14 th day of rehabilitation. There was little difference between the three groups, and the means for all the birds have been used to express the results. The food intakes of some of the cockerels and pigs were measured for the first 4 weeks of rehabilitation. The cockerels were fed six times each day. They were placed on a large table and watched till they had taken their fill. Any scatterings were brushed up and weighed. The pigs were treated similarly, but the animals were not fed on a table for the food was moistened and there was never any loss.

Two sets of apparatus were used for the determination of the $\mathrm{O}_{2}$ consumption rates; both were similar in principle to the respiration chamber described by Mount (1959). The earlier experiments with pigs were made in one chamber, and the later experiments with pigs, and all those involving cockerels, were made in the second machine.

\section{RESULTS}

\section{Cockerels}

Fig. I shows the changes in body-weight and Fig. 2 rectal temperature and $\mathrm{O}_{2}$ consumption $/ \mathrm{kg} \mathrm{min}$. The standard deviation of $\mathrm{O}_{2}$ consumption rates could not be calculated as some of the determinations were made on groups of four or five birds. The body-weights rose steadily and almost linearly. The rectal temperatures rose quickly in the first few days, and were within normal limits by the 6th day. The $\mathrm{O}_{2}$ consumption rates were only $17 \mathrm{ml} / \mathrm{kg} \mathrm{min}$ at first, but they also rose quite rapidly initially, although thereafter more slowly, and reached $24 \mathrm{ml} / \mathrm{kg} \mathrm{min}$ by the 14 th day. Fig. I also shows the increase in weight and Fig. 2 the $\mathrm{O}_{2}$ consumption rates of normal brood mates as they grew over the same range. They gained weight very little faster than the birds which had been undernourished, and their $\mathrm{O}_{2}$ consumptions fell as their weight increased, from $30 \mathrm{ml} / \mathrm{kg}$ min to about $25 \mathrm{ml} / \mathrm{kg}$ min at the close of the observations, which was not far from the mean for the rehabilitated birds. The $\mathrm{O}_{2}$ 
uptake expressed per bird per min was $2.9 \mathrm{ml}$ when the cockerels were undernourished, but it had risen to $8.9 \mathrm{ml}$ by the $14^{\text {th }}$ day of rehabilitation. The corresponding figures for well-nourished brood mates of approximately the same weights were $5.0 \mathrm{ml} /$ bird $\min$ and $9.2 \mathrm{ml} /$ bird $\min$ respectively.

Table I shows the food conversion ratios for four of the cockerels which were studied for the first 4 weeks of their rehabilitation; $100 \mathrm{~g}$ of the food provided $19 \mathrm{~g}$ protein and $356 \mathrm{kcal}$.

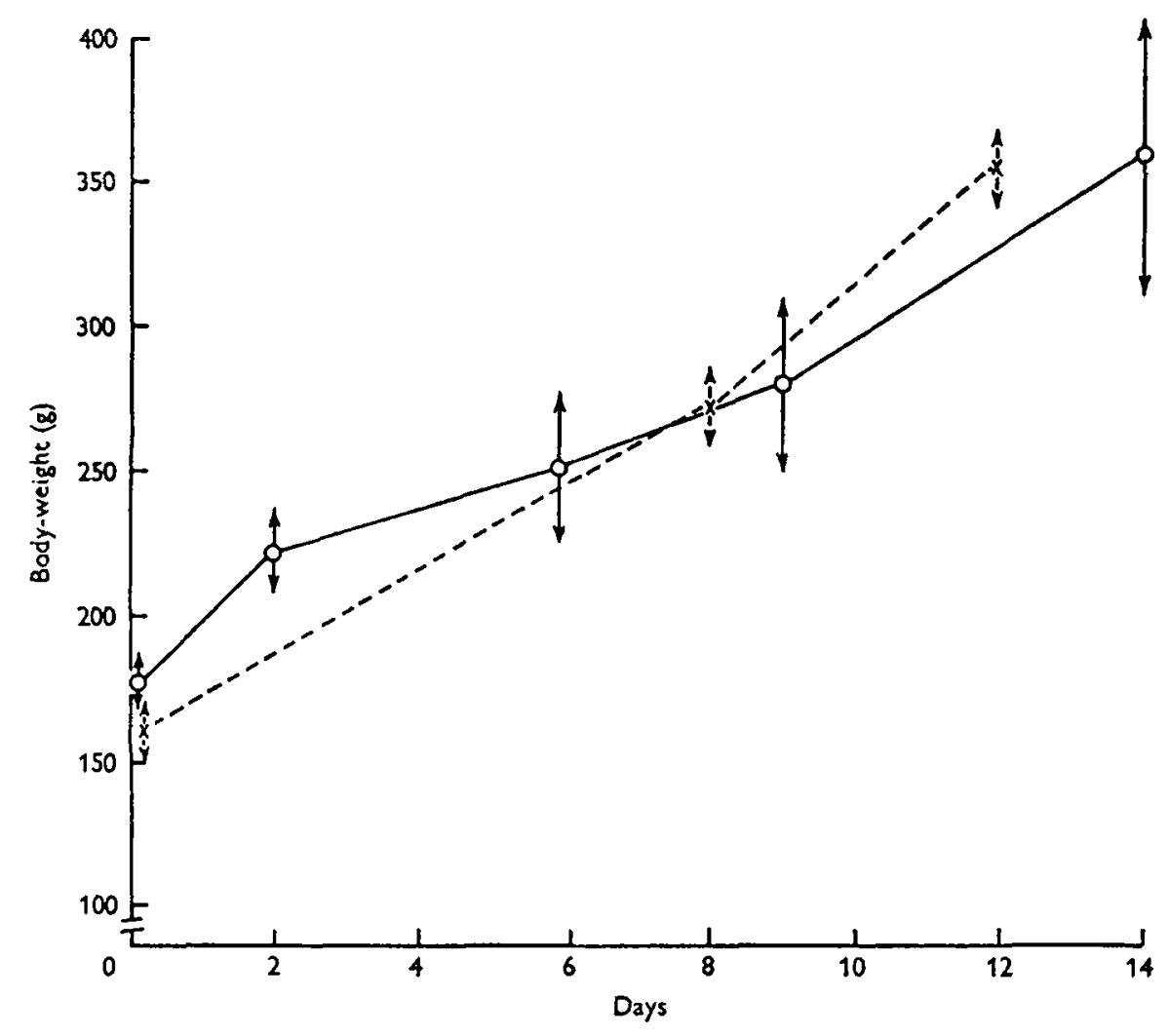

Fig. 1. Early effects of rehabilitation on the body-weights of undernourished cockerels. The body-weights of normal cockerels growing over the same weight range are also shown. The arrows show the standard deviations. $\mathrm{O}-\mathrm{O}$, rehabilitating birds; $\times \ldots . .-\times$, normal birds.

\section{Pigs}

Table 2 shows the natural variations in the temperatures and $\mathrm{O}_{2}$ consumption rates of one undernourished pig I year old and weighing $5.3 \mathrm{~kg}$. It was brought to the laboratory on 3 different days for observation, and treated before arrival in the same way on each occasion. Table 2 also gives figures for a well-nourished animal of the same size. The lability of the rectal temperature and of $\mathrm{O}_{2}$ uptake in the undernourished animal was considerable. The $\mathrm{O}_{2}$ uptake, for example, varied from 3.8 to $8.1 \mathrm{ml} / \mathrm{kg} \min$ at $30^{\circ}$. There was, however, always a considerable difference between the figures obtained for the normal and for the undernourished animal. 
Table 3 shows the mean values for the body-weights and rectal temperatures on arrival at the laboratory, and for the $\mathrm{O}_{2}$ consumption rates at $1 \mathrm{I}^{\circ}$ and $30^{\circ}$. The results for the animals before rehabilitation were similar to those previously obtained. The mean body-weight $(5.68 \mathrm{~kg})$ was a little lower, and the rectal temperature a little higher $\left(36 \cdot 6^{\circ}\right)$ than it had been before. The mean $\mathrm{O}_{2}$ consumption at $11^{\circ}$ was almost the same, that at $30^{\circ}$ appreciably lower, namely $6.34 \mathrm{ml} / \mathrm{kg} \mathrm{min}$, and more like the $\mathrm{O}_{2}$ consumptions obtained in the previous experiments after shorter periods of undernutrition. With rehabilitation the body-weights rose rapidly and almost linearly, and

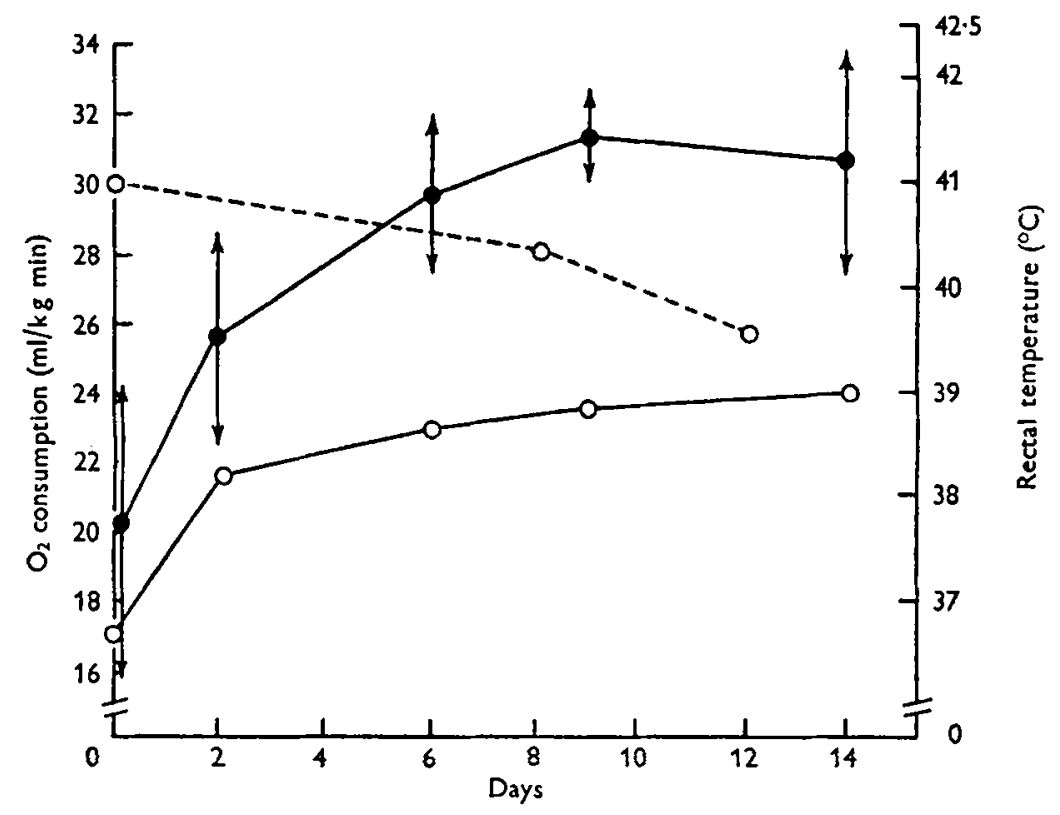

Fig. 2. Early effects of rehabilitation on the oxygen consumption and rectal temperature of undernourished cockerels. The oxygen consumption of normal cockerels growing over the same weight range is also shown. The arrows indicate the standard deviations. $\mathrm{O}-\mathrm{O}$, $\mathrm{O}_{\mathbf{z}}$ consumption, rehabilitating birds; - - , rectal temperature, rehabilitating birds; $\mathrm{O}-.-\mathrm{O}, \mathrm{O}_{2}$ consumption, normal birds.

Table 1. Ratio of the food eaten ( $g$ ) by four cockerels during rehabilitation to gain in body-weight $(g)$

$\begin{array}{ccccc}\begin{array}{c}\text { Period of } \\ \text { rehabilitation } \begin{array}{c}\text { Bird no. } \\ \text { (days) }\end{array}\end{array} & 1 & 2 & 3 & 4 \\ 3-10 & 2.5 & 2.9 & 3.0 & 2.6 \\ 10-17 & 2.0 & 2.0 & 1.9 & 2.3 \\ 17-24 & 2.6 & 2.9 & 2.5 & 3.0 \\ 24-31 & 4.1 & 3.4 & 3.5 & 2.5\end{array}$

the animals gained about $2 \mathrm{~kg}$ in the Io days. Like those of the cockerels, the rectal temperatures of the pigs were almost normal after the first 4 days of rehabilitation, and the mean was within normal limits, $39^{\circ} 0^{\circ}$, by the roth day of rehabilitation. The skin temperatures rose rather less, from $33^{\cdot} 6 \pm \mathrm{r} \cdot 25$ to $34^{\cdot 8} \pm 1 \cdot 21^{\circ}$. As in the cockerels, 
Table 2. Natural variations in rectal and skin temperatures and oxygen consumption of an undernourished $(U)$ pig weighing $5.3 \mathrm{~kg}$, aged 1 year, and of a well-nourished $(C)$ control weighing $5.0 \mathrm{~kg}$, aged 15 days

\begin{tabular}{|c|c|c|c|c|c|}
\hline \multirow{2}{*}{$\begin{array}{l}\text { Nature of } \\
\text { animal and } \\
\text { date }\end{array}$} & \multirow{2}{*}{$\begin{array}{c}\text { Ambient } \\
\text { temperature } \\
\left({ }^{\circ} \mathrm{C}\right)\end{array}$} & \multirow{2}{*}{$\begin{array}{c}\text { Rectal } \\
\text { temperature } \\
\left({ }^{\circ} \mathrm{C}\right)\end{array}$} & \multirow{2}{*}{$\begin{array}{c}\text { Skin } \\
\text { temperature } \\
\left({ }^{\circ} \mathrm{C}\right)\end{array}$} & \multicolumn{2}{|c|}{$\mathrm{O}_{2}$ consumption } \\
\hline & & & & $\mathrm{ml} / \mathrm{kg} \min$ & $\mathrm{ml} / \mathrm{kg}^{\mathrm{t}} \mathrm{min}$ \\
\hline $\begin{array}{l}\mathrm{U}, 7 . \text { vi. } 6 \mathrm{I} \\
\mathrm{U}, 7 . \text { vi. } 6 \mathrm{I} \\
\mathrm{U}, 9 . \text { vi. } 6 \mathrm{I} \\
\mathrm{U}, \text { 16. vi. } 6 \mathrm{I}\end{array}$ & $\begin{array}{l}30 \cdot 1 \\
29 \cdot 9 \\
30 \cdot 0 \\
30 \cdot 2\end{array}$ & $\begin{array}{l}38 \cdot 4 \\
37 \cdot 4 \\
37 \cdot 0 \\
37 \cdot 6\end{array}$ & $\begin{array}{l}34 \cdot 8 \\
34 \cdot 8 \\
32 \cdot 5 \\
33 \cdot 4\end{array}$ & $\begin{array}{l}6 \cdot 7 \\
3 \cdot 8 \\
6 \cdot 2 \\
8 \cdot 1\end{array}$ & $\begin{array}{r}11 \cdot 7 \\
6.6 \\
10 \cdot 7 \\
14.2\end{array}$ \\
\hline Mean, U & 30.0 & $37 \cdot 6$ & $33 \cdot 9$ & $6 \cdot 2$ & $10 \cdot 8$ \\
\hline C, 9. vi. $6 \mathrm{I}$ & $30 \cdot 0$ & $40 \cdot 6$ & $35^{\cdot} 8$ & $11 \cdot 4$ & 19.5 \\
\hline $\begin{array}{l}\mathrm{U}, 7 . \text { vi. 6I } \\
\mathrm{U}, 7 . \text { vi. 6I } \\
\mathrm{U}, 9 . \text { vi. 6I } \\
\mathrm{U}, \text { I6. vi. 6I }\end{array}$ & $\begin{array}{l}11 \cdot 0 \\
10 \cdot 9 \\
11 \cdot 2 \\
11 \cdot 2\end{array}$ & $\begin{array}{l}37 \cdot 7 \\
37 \cdot 0 \\
37 \cdot 6 \\
36 \cdot 8\end{array}$ & $\begin{array}{l}32 \cdot 2 \\
31 \cdot 0 \\
32 \cdot 4 \\
30 \cdot 1\end{array}$ & $\begin{array}{r}13 \cdot 0 \\
9 \cdot 3 \\
11 \cdot 2 \\
I I \cdot I\end{array}$ & $\begin{array}{l}22 \cdot 6 \\
16 \cdot 2 \\
20 \cdot 2 \\
19 \cdot 3\end{array}$ \\
\hline Mean, U & $I 1 \cdot 1$ & $37 \cdot 3$ & $31 \cdot 4$ & $I I \cdot 2$ & $19 \cdot 6$ \\
\hline C, 9. vi. $6 \mathrm{I}$ & II.O & $40 \cdot 2$ & $33 \cdot 4$ & $26 \cdot 4$ & $45 \cdot 1$ \\
\hline
\end{tabular}

Table 3. Mean values with standard deviations for body-weight, oxygen consumption and rectal temperature of seventeen undernourished and thirteen rehabilitating pigs

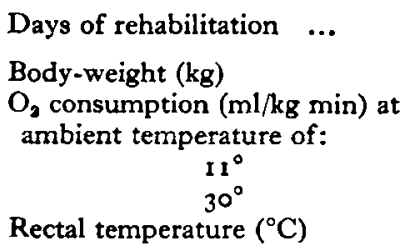

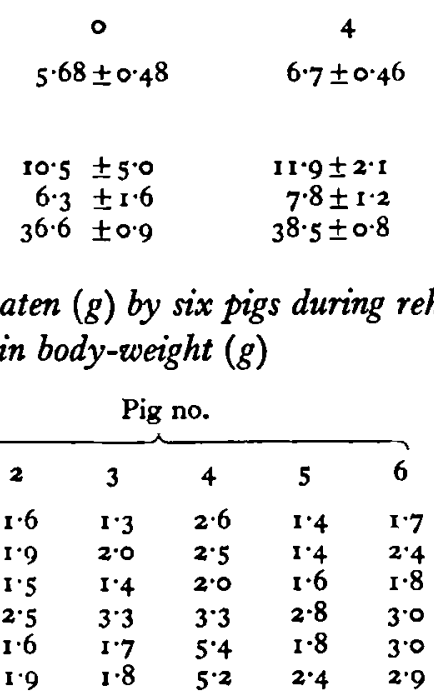

the $\mathrm{O}_{2}$ uptake/kg min, which had been subnormal during the period of undernutrition (see Table 2 and $\mathrm{McC}$ ance \& Mount, $\mathrm{r} 960$ ), tended to rise both at $\mathrm{II}^{\circ}$ and at $30^{\circ}$. There were, however, considerable individual differences, and in some animals the $\mathrm{O}_{2}$ consumption $/ \mathrm{kg}$ min did not rise till after the $4^{\text {th }}$ day, and a few values were lower on this day than before rehabilitation began. Since an increase in body-weight accompanied the rise in $\mathrm{O}_{2}$ consumption $/ \mathrm{kg}$ min during rehabilitation, the rise in $\mathrm{O}_{2}$ consumption would have been greater than that shown in Table 3 had it been expressed per unit of surface area. 
Table 4 shows the food conversion ratios for four pigs for the first 4 weeks of rehabilitation. The quantity of food during these weeks was increased after 7 or 8 days by the addition of the 'meal mixture' (McCance, 1960), and the quantity of commercial pig pellets gradually reduced after another week. The percentage of protein in the food, therefore, fell from 18 to $14 \%$ during about 4 weeks. The food had a calorific value of $350 \mathrm{kcal} / \mathrm{r} 00 \mathrm{~g}$.

\section{DISCUSSION}

Both the cockerels and the pigs were affected in a similar way by undernutrition, and both responded in a similar way to rehabilitation. In both, the body-weight and the temperature were subnormal during undernutrition and increased at once on rehabilitation (cf. Rogers, 1919), and the same was true in general terms of the $\mathrm{O}_{2}$ uptake/ $\mathrm{kg}$ min. It is probable, therefore, that these observations can be taken to apply to other species. It has in fact been shown that prolonged undernutrition leads to a fall in body temperatures and to a low metabolic rate in rats (Horst, Mendel \& Benedict, 1934), in other species of animal and in man (Kerpel-Fronius, Varga \& Kun, 1954, and see also McCance \& Mount, 1960).

Montgomery (1962) found that in marasmic infants the basal metabolic rate $/ \mathrm{kg}$ $24 \mathrm{~h}$ was not always subnormal but that it rose during rehabilitation, sometimes before there was any gain in weight. The rise continued to a plateau which might be twice the normal value for the weight and approached the value for a healthy child of the same age. There was no evidence of a similar effect in the pigs or in the cockerels. Mendes \& Waterlow (1958), Waterlow (1961) and Montgomery (1962) have recorded that during the rehabilitation of children with protein-deficiency malnutrition in Jamaica there may be a considerable delay before a satisfactory gain in weight begins, and that a calorie intake per $\mathrm{kg}$ far above the normal may be required to establish it. Mendes \& Waterlow were not able to reproduce this effect in rats, and there appears to be no suggestion of it in pigs or cockerels. Indeed, the food conversion ratios given in Tables $I$ and 4 are in the normal range, those for the cockerels (Table I) being nearly all in the range of from $2 \cdot 0$ to 3.2 given by Ewing (1947) for healthy birds $3^{-}$ 4 weeks old and weighing, therefore, about $35^{\circ} \mathrm{g}$. There is no proven explanation of this species difference at present. It may lie in the large proportion of the body of an undernourished infant accounted for by the brain (Montgomery, 1962) or in the nature of its food (Waterlow, 196r) or in the very different growth rates of these various species. It has been suggested that infants fail to grow after prolonged undernutrition because the pituitary does not produce enough growth hormone to initiate growth (Mönkeberg, Donoso, Oxman, Pak \& Meneghello, 1963), but if so the human infant must differ in this feature from the experimental animals.

\section{S U M M A R Y}

1. By giving too little of a diet otherwise satisfactory pigs were kept to a weight of about $5.8 \mathrm{~kg}$ for a year and cockerels to one of $175 \mathrm{~g}$ for 6 months.

2. At the end of these times the rectal and skin temperatures and oxygen consumption rates were subnormal. 
3. During the first days of rehabilitation the rectal and skin temperatures returned to normal levels, the weights increased rapidly, and the $\mathrm{O}_{2}$ consumption rate $/ \mathrm{kg}$ body-weight rose.

The authors are grateful to Miss Ann Baish for permission to use some of her results, and they are indebted to $\mathrm{Mr}$ I. B. Start for skilful technical assistance. The animals were cared for conscientiously by Terry Cowen.

\section{REFERENCES}

Ewing, W. R. (1947). Poultry Nutrition, 3rd ed. South Pasadena: The Author.

Horst, K., Mendel, L. B. \& Benedict, F. G. (1934). F. Nutr. 8, r 39.

Kerpel-Fronius, E., Varga, F. \& Kun, K. (1954). Ann. paediat. 183, r.

McCance, R. A. (1960). Brit. F. Nutr. 14, 59.

McCance, R. A. \& Mount, L. E. (1960). Brit. F. Nutr. 14, 509.

Mendes, C. B. \& Waterlow, J. C. (1958). Brit. F. Nutr. 12, 74.

Mönkeberg, F., Donoso, G., Oxman, S., Pak, N. \& Meneghello, J. (1963). Pediatrics, Springfield, 3I, 58 .

Montgomery, R. D. (1962). F. clin. Invest. 41, 1653.

Mount, L. E. (1959). Ұ. Physiol. 147, 333.

Rogers, F. T. (1919). Amer. F. Physiol. 49, 27 r.

Waterlow, J. C. (196r). F. trop. Pediat. 7, 16. 